\title{
Rapid high-throughput analysis of DNasel hypersensitive sites using a modified Multiplex Ligation-dependent Probe Amplification
} approach

\author{
Thomas Ohnesorg 1 , Stefanie Eggers ${ }^{1}$, Wouter N Leonhard ${ }^{2}$, \\ Andrew H Sinclair ${ }^{1}$ and Stefan J White*1
}

\begin{abstract}
Address: ${ }^{1}$ Murdoch Children's Research Institute and Department of Paediatrics, University of Melbourne, Royal Children's Hospital, Parkville, VIC, Australia and ${ }^{2}$ Center for Human and Clinical Genetics, Leiden University Medical Center, Leiden, The Netherlands

Email: Thomas Ohnesorg - thomas.ohnesorg@mcri.edu.au; Stefanie Eggers - stefanie.eggers@mytum.de;

Wouter N Leonhard - w.n.leonhard@lumc.nl; Andrew H Sinclair - andrew.sinclair@mcri.edu.au; Stefan J White* - stefan.white@mcri.edu.au

* Corresponding author
\end{abstract}

Published: 4 September 2009

Received: 15 January 2009

BMC Genomics 2009, 10:412 doi:10.1 |86/147|-2164-10-4|2

Accepted: 4 September 2009

This article is available from: http://www.biomedcentral.com/I47I-2/64/I0/4I2

(C) 2009 Ohnesorg et al; licensee BioMed Central Ltd.

This is an Open Access article distributed under the terms of the Creative Commons Attribution License (http://creativecommons.org/licenses/by/2.0), which permits unrestricted use, distribution, and reproduction in any medium, provided the original work is properly cited.

\begin{abstract}
Background: Mapping DNasel hypersensitive sites is commonly used to identify regulatory regions in the genome. However, currently available methods are either time consuming and laborious, expensive or require large numbers of cells. We aimed to develop a quick and straightforward method for the analysis of DNasel hypersensitive sites that overcomes these problems.

Results: We have developed a modified Multiplex Ligation-dependent Probe Amplification (MLPA) approach for the identification and analysis of genomic regulatory regions. The utility of this approach was demonstrated by simultaneously analysing 20 loci from the ENCODE project for DNasel hypersensitivity in a range of different cell lines. We were able to obtain reproducible results with as little as $5 \times 10^{4}$ cells per DNasel treatment. Our results broadly matched those previously reported by the ENCODE project, and both technical and biological replicates showed high correlations, indicating the sensitivity and reproducibility of this method.

Conclusion: This new method will considerably facilitate the identification and analysis of DNasel hypersensitive sites. Due to the multiplexing potential of MLPA (up to 50 loci can be examined) it is possible to analyse dozens of DNasel hypersensitive sites in a single reaction. Furthermore, the high sensitivity of MLPA means that fewer than $10^{5}$ cells per DNasel treatment can be used, allowing the discovery and analysis of tissue specific regulatory regions without the need for pooling. This method is quick and easy and results can be obtained within 48 hours after harvesting of cells or tissues. As no special equipment is required, this method can be applied by any laboratory interested in the analysis of DNasel hypersensitive regions.
\end{abstract}

\section{Background}

Open chromatin is a characteristic of genomic loci with regulatory functions. These regions are preferentially digested by DNaseI [1], and the identification of DNaseI hypersensitive sites is frequently used to identify and analyse regulatory regions such as promoters, enhancers and 
silencers $[2,3]$. However, currently available methods have significant limitations. A commonly used approach involves Southern blotting, but this is time consuming, usually requires radioactivity and is limited to short stretches of DNA. Several PCR-based methods have been described $[4,5]$, but these do not readily allow multiplexing. Recent reports of large scale analysis of DNaseI hypersensitive sites have used either microarrays [6-9] or deep sequencing $[9,10]$. Whilst valuable for genome wide analysis, the costs involved are a limiting factor for many applications (such as comparing different developmental stages or tissues). Another disadvantage of those methods is that they usually require many millions of cells. For $e x$ vivo studies, this might require extensive pooling of tissues, meaning that these methods are not suitable for all applications.

Multiplex Ligation-dependent Probe Amplification (MLPA) was originally developed to detect deletions and duplications in genomic DNA [11], and has become popular in diagnostic settings for a range of disorders $[12,13]$. It has since been modified for several other applications as well, including methylation analysis [14], mRNA expression analysis [15], identifying copy number variation in normal populations $[16,17]$, genotyping of mouse models $[18,19]$ and measuring the efficiency of Cre-mediated recombination in mouse models [20]. The principle advantages of this method are the sensitivity and multiplexing potential. It can be used to analyse up to 50 genomic loci with as little as $20 \mathrm{ng}$ genomic DNA in a single reaction. Furthermore, the only equipment that is required is a thermocycler and DNA sequencer, readily available to most researchers.

We describe here a quick and straightforward protocol for analysing DNaseI hypersensitive sites. This is demonstrated by the analysis of 20 different loci in a single reaction, based on data published by the ENCODE consortium [21].

\section{Results \\ Probe design}

Figure 1 outlines the protocol used in this study. To examine the general feasibility of our approach, we designed 11 probes to cover randomly chosen DNaseI hypersensitive sites in HeLa cells as published by the ENCODE consortium [21]. In addition, nine probes were designed in regions that showed no evidence of DNaseI hypersensitivity. To be able to cover larger genomic regions and to give greater flexibility in probe design we employed the recently developed extension MLPA [20]. All 20 probes were combined in a single mix, and could be differentiated from each other on the basis of length (the final product length range was 94-207 bp).

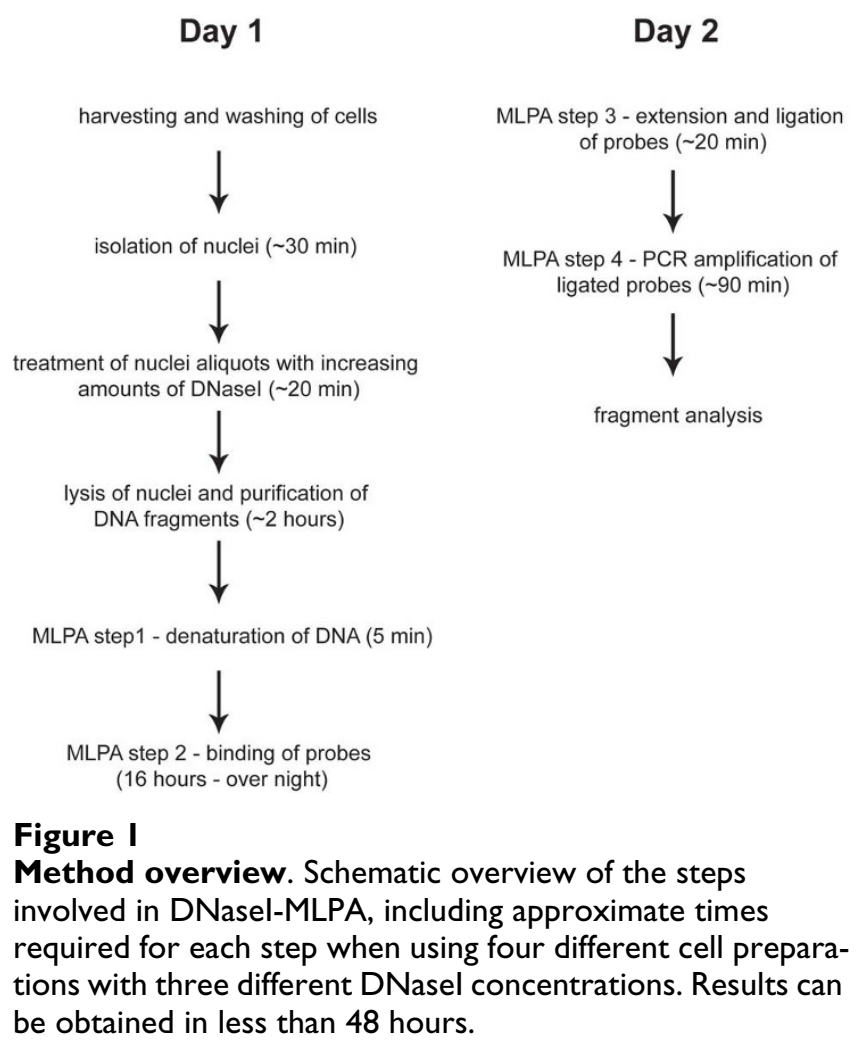

\section{Nuclei isolation and DNasel treatment}

We tested different methods for the isolation of nuclei, with the Ne-Per Kit (Thermo Scientific) found to be most suitable. Although intended for the isolation and separation of nuclear and cytoplasmic proteins, it proved to be useful for the isolation of nuclei. Another obstacle to overcome was the isolation of the genomic DNA. This approach requires efficient recovery of very long as well as very short fragments of genomic DNA. Unfortunately, DNA obtained using the standard method for this task, phenol-chloroform purification, is not suitable for use with MLPA, as traces of phenol are known to interfere with the enzymatic reactions. Instead we used the HighPure PCR Purification Kit (Roche), which, according to the manufacturer, is suitable for the isolation of fragments of up to $50 \mathrm{~kb}$. As expected, in our experiments the recovery of DNA from the untreated and therefore most intact sample, was often least efficient, however, the quality and quantity of the DNA was still sufficient for MLPA analysis. Figure 2 shows a typical example of digested DNA obtained after treating isolated nuclei with increasing amounts of DNaseI and purification.

\section{Analysis of DNasel hypersensitive sites in HeLa cells}

We next used the same probe mix to analyse the DNaseI hypersensitivity of DNA within intact nuclei of HeLa cells. 


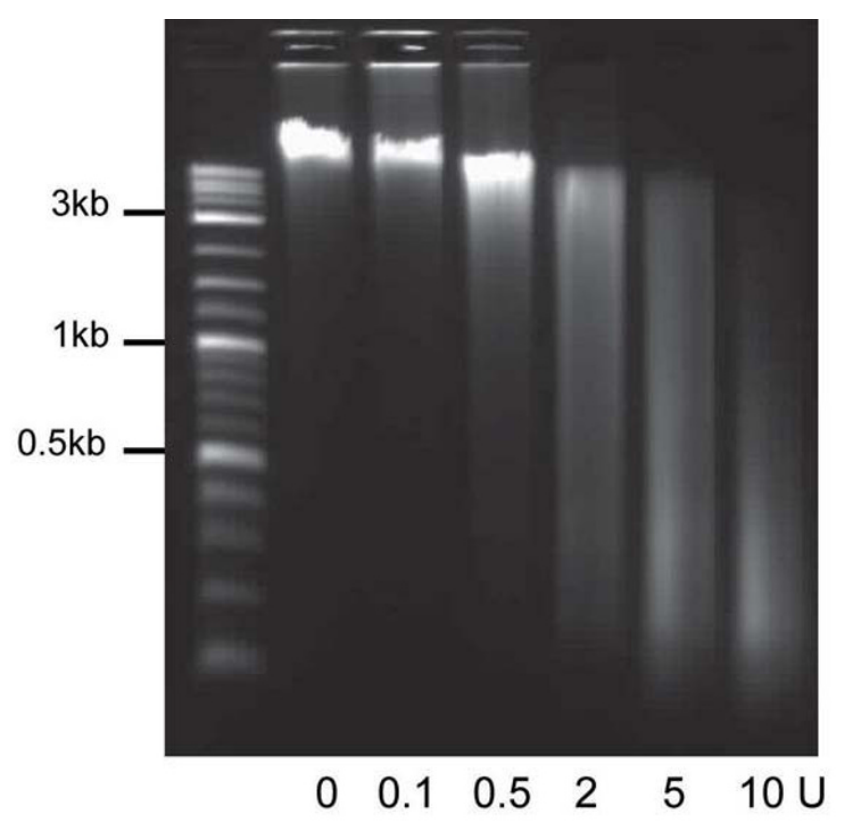

Figure 2

Example of DNasel digest. Typical result of the analysis of DNasel treated samples by agarose gel electrophoresis. The untreated sample and those digested with 0.5 and 2 units of DNasel were used in subsequent experiments. $L=D N A$ ladder.

Figure 3A shows typical peak patterns obtained using nuclei aliquots digested with increasing amounts of $\mathrm{DNa}-$ seI. Several peaks show significantly decreased peak height with increased DNaseI concentration, while others remain virtually unchanged. Nine of 11 probes targeting previously described DNaseI hypersensitive sites in HeLa cells show a clear decrease in normalized peak heights (defined as $<75 \%$ of the equivalent peak in undigested DNA), whereas all nine probes targeting non-sensitive loci show no significant decrease (figure 3B). These results were highly reproducible, with the technical and biological replicates giving an $\mathrm{r}^{2}>0.9$.

We also tested the same probe mix on DNA directly isolated from HeLa cells. As can be seen in Figure 3C, there are no significant changes in normalized peak heights with increasing DNaseI digestion. This was expected as these DNA samples should have no chromatin structure, and all cuts by DNaseI should therefore occur in a random fashion.

\section{Comparison of results using other cell lines}

We then analysed the same 20 loci for DNaseI hypersensitivity in other cell lines. For this comparison we used HEK293, C28 and S97 cells. While the results for C28 cells were very similar to those of HeLa cells (data not shown), we could identify differences in sensitivity for several probes in HEK293 and S97 cells. As shown in Figure 4, some probes identifying hypersensitive sites in HeLa cells stay unchanged in the other cell lines (probes S9 in HEK293 cells, S6 in S97 cells) and two of the probes not showing the expected sensitivity in HeLa cells (S3 and S4) do show sensitivity in HEK293 cells.

\section{Determining the minimum cell number}

We also tried to determine the minimum cell number that could be used with this approach. As we were able to obtain robust results and sufficient DNA for several replicates from aliquots containing nuclei from about $2.5 \times$ $10^{5}$ cells, we estimated the lower limit of required cells to be around $5 \times 10^{4}$ (theoretically 300 ng DNA). To confirm this number, we used aliquots of $5 \times 10^{4} \mathrm{HeLa}$ cells and treated them as described above and compared the results with those obtained from experiments using $2.5 \times$ $10^{5}$ cells per aliquot. Figure 5 shows the comparison of results from $5 \times 10^{4}$ and $2.5 \times 10^{5}$ cells $\left(r^{2}=0.97\right)$.

\section{Discussion}

We describe here a simple technique that allows the rapid analysis of many DNaseI hypersensitive sites using little starting material. For a proof of principle we chose loci that had been analysed by both array analysis and deep sequencing as part of the ENCODE project [21].

We used 20 probes in one reaction (11 sensitive, 9 nonsensitive in HeLa cells according to ENCODE data). Nine of 11 of the probes targeted to hypersensitive sites showed the expected decrease in peak height for HeLa cells. The fact that two sensitive sites did not show the expected drop in peak heights is probably due to different growth conditions, differences in passage numbers or to our batch of HeLa cells being different from the one used in the ENCODE study rather than to limitations of our method. This is supported by the high correlation observed for both technical and biological replicates $\left(\mathrm{r}^{2}>\right.$ 0.9 ) and the fact that those two probes showed sensitivity in HEK293 cells.

We also examined three other cell lines, in order to examine the cell line specificity of our experimental approach. We could show clear differences in hypersensitivity for some loci compared to HeLa cells. Again, the conclusion that these are cell type-specific differences is supported by the concordance of replicate experiments $\left(r^{2}>0.9\right)$.

To determine suitable DNaseI digestion conditions for our method, a range of different DNaseI concentrations and incubation conditions were tested. Incubating the digestion reactions with the indicated DNaseI amounts at room temperature for 20 minutes gave more reproducible 

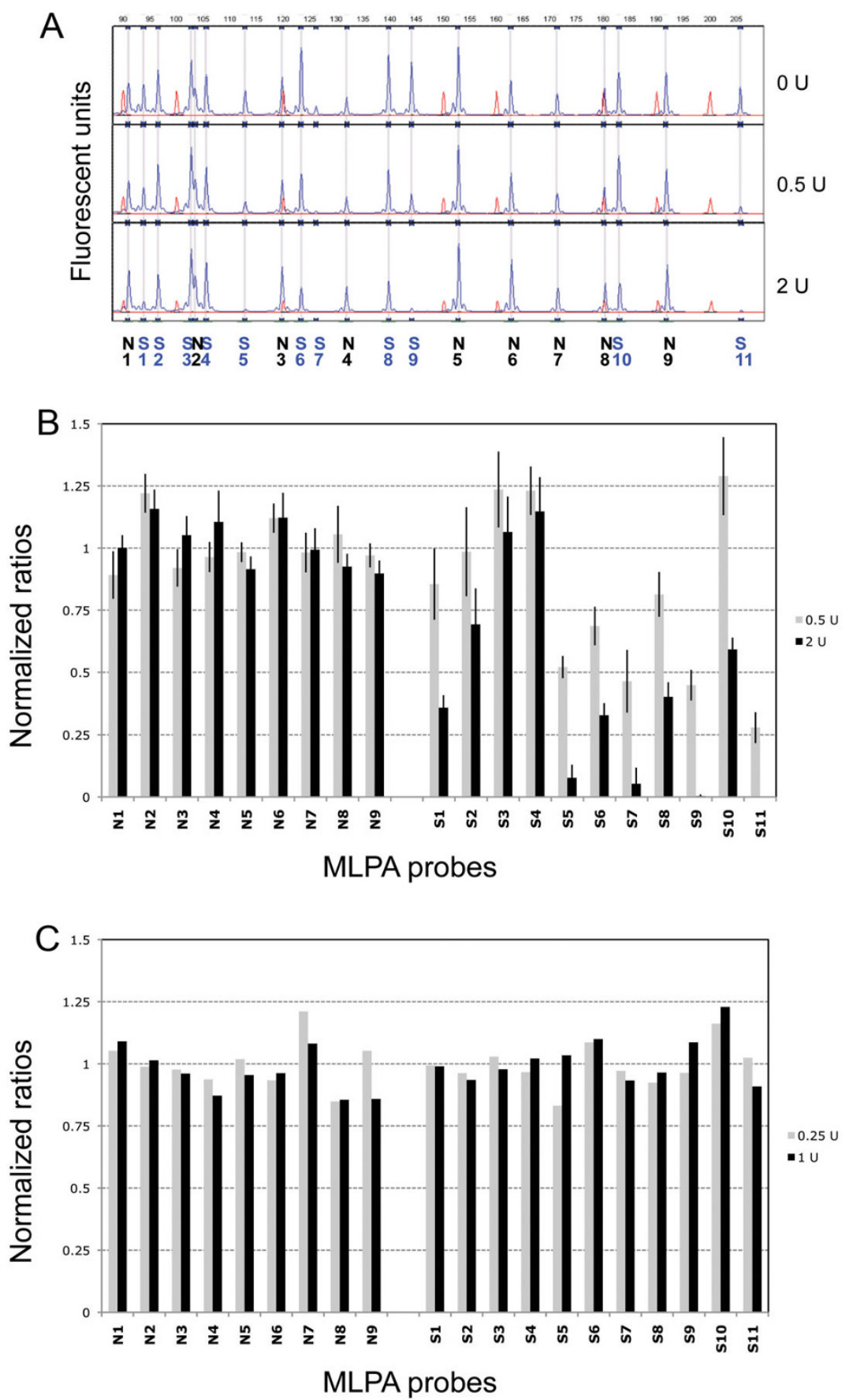

Figure 3

MLPA on DNA from HeLa cells. A) Representative MLPA peak patterns obtained from nuclei isolated from HeLa cells and subsequent treatment with $0,0.5$ and 2 units of DNasel. Red peaks represent size standards, blue peaks the signals from the probes after PCR amplification. Black numbers show probes designed to bind to non-sensitive regions, blue numbers to sensitive regions for HeLa cells as published by the ENCODE consortium. B) Analysis of experiment shown in 3A. Data were obtained from two independent experiments and two technical replicates $(n=4)$. Results shown as mean \pm SD. C) Analysis of data derived from DNasel treatment of naked DNA isolated from HeLa cells. In this case DNasel digestion was with either 0.25 units or I unit DNasel for I minute on ice, as this DNA was far more susceptible to degradation than DNA in intact nuclei. Probes are grouped into sensitive and non-sensitive, and then ordered according to their length. N: non-sensitive, S: sensitive for HeLa cells as published by the ENCODE consortium. 

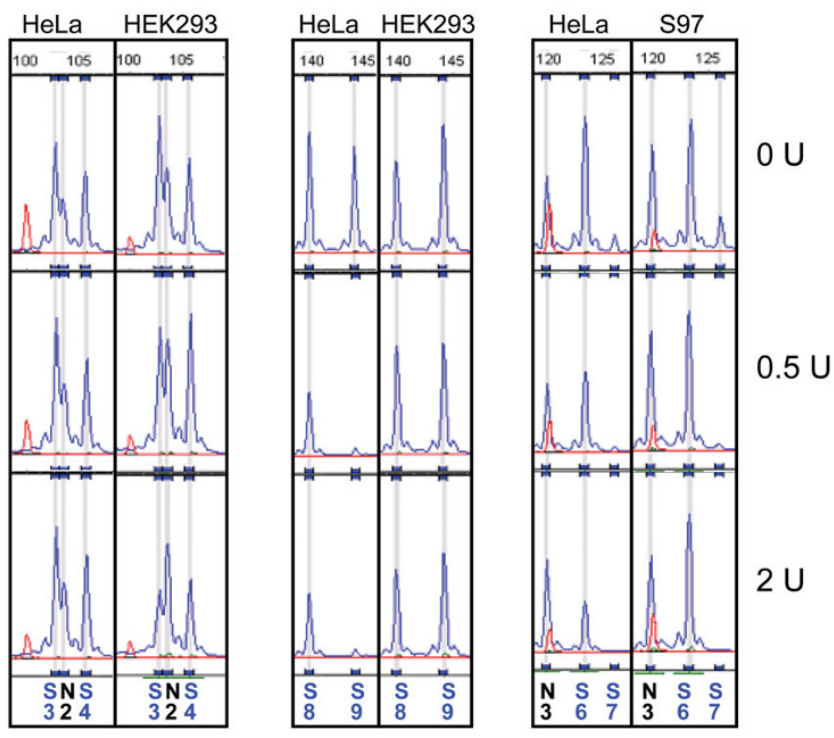

Figure 4

Differences in DNasel sensitivity between the tested cell lines. The majority of probes gave similar peak patterns in all tested cell lines, with the exceptions shown here. As can be seen on the left, the two regions not showing sensitivity in HeLa cells are sensitive in HEK293 cells. On the other hand, region S9 in HEK293 and S6 in S97 cells show no sign of sensitivity in contrast to HeLa cells.

results than, for example, using less DNaseI and incubating at $37^{\circ} \mathrm{C}$ or incubations on ice (data not shown). By analysing the digested DNA on an agarose gel it was possible to identify the most appropriate conditions. Most of our experiments were carried out using nuclei from $2.5 \times$ $10^{5}$ cells per DNaseI digestion aliquot, providing sufficient DNA for several technical replicates. However, in the case of HeLa cells this number could be reduced to only 5 $\times 10^{4}$ cells, still providing highly reproducible results as shown by an $r^{2}$ of 0.97 when comparing the results of the experiments with both cell numbers. Furthermore, we found that two different DNaseI concentrations and an undigested control are sufficient to analyse hypersensitive sites, which reduces the amount of total starting material required to about $1.5 \times 10^{5}$ cells.

Although we have used 20 probes in this study, there is the potential to significantly increase the degree of multiplexing. Reducing the interprobe spacing to 3 bp would allow up to 40 loci to be examined. Indeed, by designing probes that can be labelled with different fluorophores $[22,23]$ it would be possible to analyse $>100$ loci in a single reaction.

\section{Conclusion}

We describe here a rapid and accurate method for assaying DNaseI hypersensitive sites. In contrast to genome-wide approaches such as deep sequencing or microarray analysis, we consider the primary strength of this approach to be when $<100$ genomic loci are being analysed. As all loci are analysed in a single reaction, relatively little starting material is required. We have shown that $<10^{5}$ cells per DNaseI treatment can be used, which will allow the study of e.g. embryonic organ development without extensive pooling. The protocol is straightforward and results can be easily obtained from many samples within 48 hours. Finally, using this method makes it possible to also detect heterozygous and homozygous deletions and duplications of the examined regions, which is an artifact that is known to occur in cultured cells.

\section{Methods \\ Cell culture}

HEK293 (human embryonic kidney cells), C28 (chondrogenic cells), HeLa (cervical cancer cells) and S97 (dermal fibroblasts) were grown in DMEM containing 10\% FBS and supplemented with L-glutamine in T-25 flasks and incubated at $37^{\circ} \mathrm{C}$ containing $5 \% \mathrm{CO}_{2}$ in a humidified atmosphere.

\section{Cell harvest and isolation of nuclei}

After reaching $95-100 \%$ of confluence, cells were washed with PBS and harvested using $1 \mathrm{ml}$ of $0.025 \%$ TrypsinEDTA. After 5-10 min incubation at $37^{\circ} \mathrm{C}$, cells were washed with $2 \mathrm{ml}$ of $10 \%$ FBS containing DMEM and carefully resuspended in a $1.5 \mathrm{ml}$ Eppendorf tube in cold PBS and placed on ice. To limit changes in chromatin structure during treatment, nuclei isolation was performed using $2.5 \times 10^{5}$ to $10^{6}$ cells as soon as possible.

For isolation of nuclei, the NE-PER Kit (Thermo Scientific) was used with the following modifications. To prevent nuclei from excessive clumping and releasing DNA, twice the recommended volumes of the solutions were used and resuspension of cells/nuclei was carried out by carefully pipetting up and down rather than vortexing. Centrifugation steps were carried out at $250 \times \mathrm{g}$ at $4{ }^{\circ} \mathrm{C}$.

\section{DNasel treatment of nuclei}

Isolated nuclei were washed in $500 \mu$ l cold DNaseI buffer containing $2 \%$ glycerol and carefully resuspended in $75 \mu \mathrm{l}$ DNaseI buffer containing 2\% glycerol. $25 \mu \mathrm{l}$ aliquots of the nuclei suspension were added to $2 \mathrm{ml}$ Eppendorf tubes containing one control without DNaseI and increasing amounts (0.5 - 2 units) of DNaseI (Promega) in $50 \mu \mathrm{l}$ DNaseI buffer containing 2\% glycerol. The solutions were mixed by carefully flicking the tubes and incubated for 20 min at room temperature $\left(23^{\circ} \mathrm{C}\right)$.

\section{Isolation and purification of DNasel treated genomic DNA} DNaseI treated nuclei were lysed by adding $250 \mu \mathrm{l}$ of nuclei lysis buffer (200 mM NaCl, $150 \mathrm{mM}$ Tris $\mathrm{HCl}$ pH 8, 


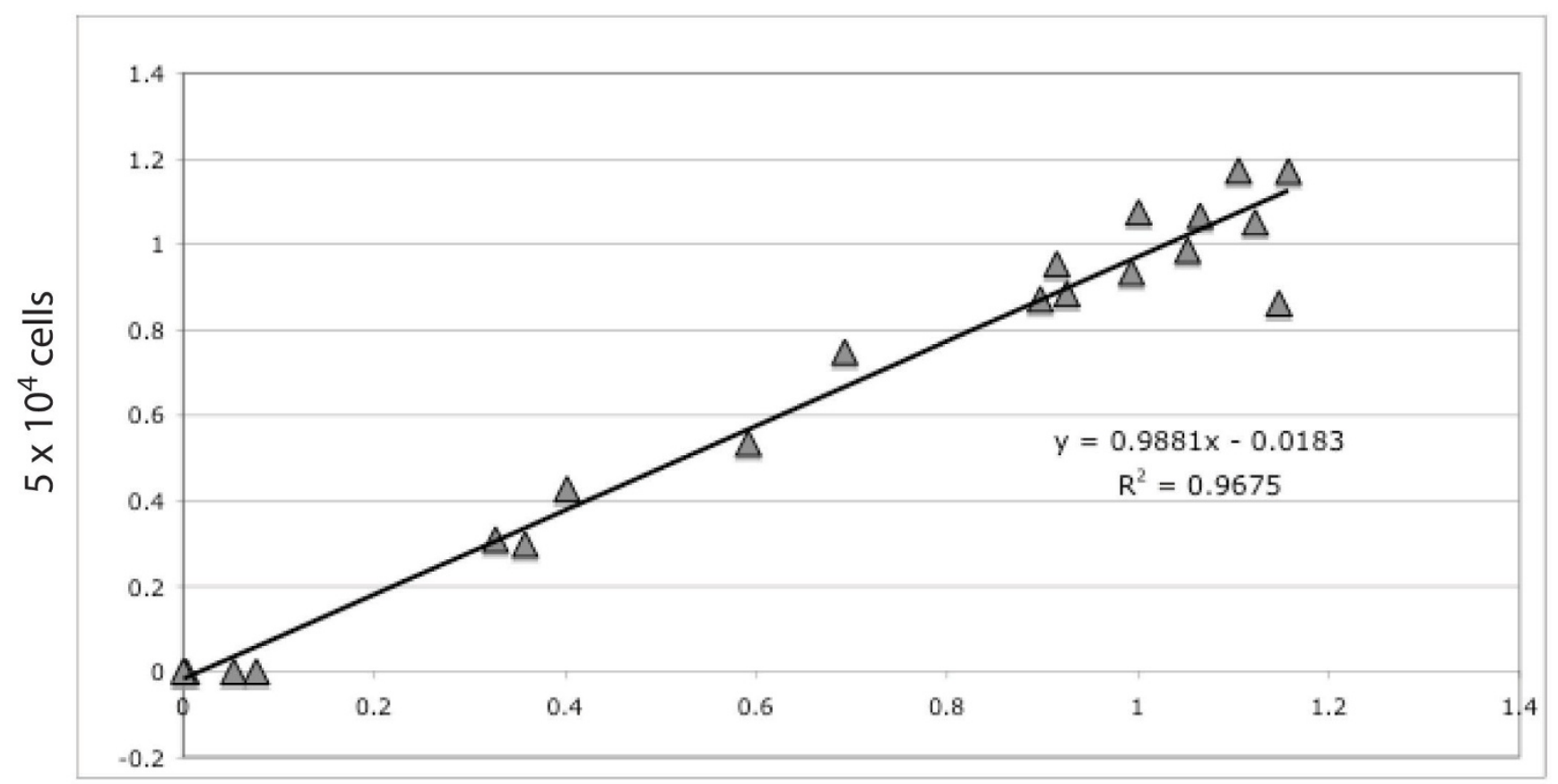

\section{$2.5 \times 10^{5}$ cells}

Figure 5

Comparison of results obtained using different cell numbers. Correlation of results obtained from experiments with 5 $\times 10^{4}(n=1)$ and $2.5 \times 10^{5}(n=4)$ HeLa cells per DNasel treatment aliquot.

$10 \mathrm{mM}$ EDTA pH 8, 0.2\% SDS) containing $50 \mu \mathrm{g}$ of Proteinase $\mathrm{K}$ and incubated for $45 \mathrm{~min}$ at $55^{\circ} \mathrm{C} .20 \mu \mathrm{g}$ of RNaseA (Sigma) was added and incubated for $30 \mathrm{~min}$ at $37^{\circ} \mathrm{C}$.

The DNaseI treated DNA was isolated and purified using the HighPure PCR Purification Kit (Roche) according to the manufacturer's instructions. DNA was eluted with 50 $\mu$ l elution buffer provided with the kit. Purified DNA was checked for quality and degree of DNaseI digestion by agarose gel electrophoresis. DNA concentrations were measured using the NanoDrop.

\section{MLPA and fragment analysis}

The MLPA probe mix was created by combining each MLPA oligonucleotide in table 1 to a final concentration of $4 \mathrm{nM}$. The extension MLPA was performed essentially as described [20]. 100-200 ng of DNaseI-treated DNA of each sample was denatured at $98^{\circ} \mathrm{C}$ for $5 \mathrm{~min}$, and allowed to cool to room temperature. $1.5 \mu \mathrm{l}$ MLPA buffer (MRC-Holland, the Netherlands) and $1.5 \mu$ MLPA probe mix were added to each sample, denatured at $95^{\circ} \mathrm{C}$ for 1 min then hybridized overnight at $60^{\circ} \mathrm{C}$. The following morning a ligation and elongation step was carried out at $54^{\circ} \mathrm{C}$ by adding $3 \mu \mathrm{l}$ ligase buffer A, $3 \mu$ l ligase buffer B, 1 $\mu$ ligase-65 (all MRC Holland, the Netherlands), $2 \mathrm{mM}$
dNTPs, 1 U Stoffel Taq polymerase (Applied Biosystems) and $\mathrm{H}_{2} \mathrm{O}$ to a final volume of $40 \mu \mathrm{l}$. After 15-20 min the ligase was inactivated by heating to $95^{\circ} \mathrm{C}$ for $5 \mathrm{~min}$. The PCR reaction consisted of $5 \mu \mathrm{l}$ of ligated mix added to $2 \mu \mathrm{l}$ SALSA PCR buffer, $1 \mu$ l SALSA enzyme buffer, $1 \mu$ l SALSA PCR primer, $0.25 \mu \mathrm{l}$ SALSA polymerase (all MRC-Holland, the Netherlands) and $15.75 \mu \mathrm{H}_{2} \mathrm{O}$. The PCR reaction started with a 1 min denaturation step at $95^{\circ} \mathrm{C}$, followed by 35-38 cycles of amplification (each cycle consisting of $95^{\circ} \mathrm{C}$ for $30 \mathrm{sec}, 58^{\circ} \mathrm{C}$ for $30 \mathrm{sec}, 72^{\circ} \mathrm{C}$ for 30 $\mathrm{sec}$ ) and concluded with $20 \mathrm{~min}$ at $72^{\circ} \mathrm{C}$.

Fragment analysis was performed on an ABI3130 capillary sequencer. Peak data was extracted using GeneMarker software (Soft Genetics) and exported to Excel (Microsoft) for further analysis.

\section{MLPA data analysis}

Basic data analysis was performed as described [24]. Peak data for the naked DNA experiment was normalised to the average of all probes in the examined samples, with all other reactions being normalized to all non-sensitive probes. To assist in visualisation of the results, normalized ratios of all untreated samples were set to 1 . 
Table I: Probe sets used in this study.

\begin{tabular}{|c|c|c|c|c|c|}
\hline Name & Probe1 & Probe2 & Genomic location & Product size & Gap size \\
\hline N1 & $\begin{array}{l}\text { 1AAGACAGAGTCAGCACCAAGC } \\
\text { AACCTG }\end{array}$ & $\begin{array}{l}\text { GAGCGGCTGCTTCTTTCTCTCTT } \\
\text { GC2 }\end{array}$ & chr2:234,440,746-234,440,797 & 94 & - \\
\hline N2 & $\begin{array}{l}\text { 1GAGCAGCACTTAGTACACAGA } \\
\text { GGCCTCTG }\end{array}$ & $\begin{array}{l}\text { CCAGGATTGCAGAAGGCTTGCAG } \\
\text { AGG2 }\end{array}$ & chrX:I53,258,524-I53,258,587 & 106 & 9 \\
\hline N3 & $\begin{array}{l}\text { 1GACCTTACTTTGATGAAGGCA } \\
\text { GTTCTGC }\end{array}$ & $\begin{array}{l}\text { CATGGGTGCCACGGTTTGAATGT } \\
\text { ATC2 }\end{array}$ & chr21:33,073,083-33,073, |6I & 121 & 25 \\
\hline N4 & $\begin{array}{l}\text { 1CCCAGTGACCTACAGTAGAAC } \\
\text { TTTTCTGTGTCC }\end{array}$ & $\begin{array}{l}\text { GCTGTTCTCCGTGCCTATCACCT } \\
\text { GTTAAAGG2 }\end{array}$ & chr2:234,444,778-234,444,867 & 132 & 26 \\
\hline N5 & $\begin{array}{l}\text { 1CAAATAGTCGAGTGGTACCTG } \\
\text { TTCAGCC }\end{array}$ & $\begin{array}{l}\text { GACAGAACTAGGAAACAAATACC } \\
\text { TCCTCATTCTATATGGC2 }\end{array}$ & chr5:|3|,655,909-|3|,656,020 & 154 & 44 \\
\hline N6 & $\begin{array}{l}\text { 1GACAGAAAATGCAGTCCAGTT } \\
\text { GGTACAAGC }\end{array}$ & $\begin{array}{l}\text { СTCTCTCAGGGCTGCTTCATGAA } \\
\text { СTTAC2 }\end{array}$ & chr2I:33,778,023-33,778, I 44 & 164 & 64 \\
\hline N7 & $\begin{array}{l}\text { 1GCTGTTCAGCATTGGTGTAAG } \\
\text { TTCTGATTCC }\end{array}$ & $\begin{array}{l}\text { CTCCAGACACCTGAGCCAAGAGA } \\
\text { AAGATT2 }\end{array}$ & chr2I:33,068,576-33,068,705 & 172 & 70 \\
\hline N8 & $\begin{array}{l}\text { 1CTAAGGTGGCCATGCTTCTCT } \\
\text { GGATTTGC }\end{array}$ & $\begin{array}{l}\text { CAGCTCATCCCGCGTCGATTCCT } \\
\text { GGAAGTGTTATC2 }\end{array}$ & chr5:|3|,660,20I-|3|,660,338 & 180 & 74 \\
\hline N9 & $\begin{array}{l}\text { 1GGAAAGAGCAGGAGAAAGGGA } \\
\text { ATCTTGG }\end{array}$ & $\begin{array}{l}\text { GTCTCTTCAGCTTGTGGGAACAA } \\
\text { ACGAG2 }\end{array}$ & chr7:27, I43,394-27, I43,543 & 192 & 94 \\
\hline $\mathrm{S} 1$ & $\begin{array}{l}\text { 1GTTTTGTACTGTGGGAGTCTG } \\
\text { AGAGCGAG }\end{array}$ & $\begin{array}{l}\text { GAGGTCCGAAAGCCGAATCACAG } \\
\text { TC2 }\end{array}$ & $\operatorname{chr} 19: 59,386,440-59,386,493$ & 96 & - \\
\hline $\mathrm{s} 2$ & $\begin{array}{l}\text { 1AGCTAAAGACGTTAGGAAACA } \\
\text { GAGCAGGGTG }\end{array}$ & $\begin{array}{l}\text { GTTGAACGGGAGTGCAGCACGGT } \\
\text { TGT2 }\end{array}$ & $\operatorname{chr} 19: 59,396,645-59,396,701$ & 99 & - \\
\hline s3 & $\begin{array}{l}\text { 1CGACTGCGAATTACTGTTTAT } \\
\text { GAGGTGACTC }\end{array}$ & $\begin{array}{l}\text { GCTGGTTCTATCGGTGGACAGTG } \\
\text { GGACATTC2 }\end{array}$ & $\operatorname{chr} 19: 59,386,0$ II-59,386,072 & 104 & - \\
\hline S4 & $\begin{array}{l}\text { 1GGTACGGAAGGCAGAATCGTA } \\
\text { CCTG }\end{array}$ & $\begin{array}{l}\text { CCTTACCAGGAAAACGGACAATC } \\
\text { TTCC2 }\end{array}$ & chr2I:33,785,757-33,785,822 & 106 & 14 \\
\hline S5 & $\begin{array}{l}\text { 1GCCACAAACTCAAATAGGAGA } \\
\text { CTCCGC }\end{array}$ & $\begin{array}{l}\text { CGGTTTTCTATTGGCTAGAGCGG } \\
\text { AGAAGC2 }\end{array}$ & chr2:234,427,935-234,428,007 & 115 & 17 \\
\hline s6 & $\begin{array}{l}\text { 1ATGGGGTACGACTTCGAATCA } \\
\text { CGTGC }\end{array}$ & $\begin{array}{l}\text { CCTGATGACCTCTAGAGGTAAAC } \\
\text { TCGTGCAC2 }\end{array}$ & chr7:27,149,886-27,149,967 & 124 & 25 \\
\hline S7 & $\begin{array}{l}\text { 1AACCTAGTCCTCCCAGGTTAG } \\
\text { CACG }\end{array}$ & $\begin{array}{l}\text { CAGCCAGCCAACGCCTCTTCTGA } \\
\text { TTG2 }\end{array}$ & $\operatorname{chr} 19: 59,396,374-59,396,459$ & 128 & 35 \\
\hline S8 & $\begin{array}{l}\text { 1TGTGAGGGACCTTGTTACTGG } \\
\text { GCAG }\end{array}$ & $\begin{array}{l}\text { CATCAGGAGGTGTACTGCCGTAC } \\
\text { CATA2 }\end{array}$ & chr5:I3I,658,970-I3I,659,067 & 140 & 46 \\
\hline S9 & $\begin{array}{l}\text { 1CCGAGAGTGGGAGCTACTCAT } \\
\text { TTTGAGG }\end{array}$ & $\begin{array}{l}\text { CССTTTAATTAAAGTCGCAGGCA } \\
\text { CCTAGG2 }\end{array}$ & chrX:153,252,787-153,252,889 & 145 & 46 \\
\hline S10 & $\begin{array}{l}\text { 1CTCTGACGTAGTGTGACCTTG } \\
\text { СTCATCC }\end{array}$ & $\begin{array}{l}\text { CGAATTCAGCTCTGCTAGGACTG } \\
\text { TTGG2 }\end{array}$ & chr5:131,657,322-|3|,657,462 & 183 & 86 \\
\hline
\end{tabular}


Table I: Probe sets used in this study. (Continued)

\begin{tabular}{llllll}
\hline S11 & $\begin{array}{l}\text { 1GCTCTTTGCATCGCTCTCTGT } \\
\text { CGG }\end{array}$ & $\begin{array}{l}\text { CGTCTTCGCACTTACGCGGAGCG } \\
\text { GTAA2 }\end{array}$ & chr2I:33,066,198-33,066,362 & 207 & II4 \\
\hline \multicolumn{3}{c}{ 1=GGGTTCCCTAAGGGTTGGA } & 2=TCTAGATTGGATCTTGCTGGC & &
\end{tabular}

$N(n)$ : non-sensitive, $S(n)$ : sensitive probes for HeLa cells according to data published by the ENCODE consortium. The genomic coordinates are from the human genome assembly of June 2006 (hg/8).

\section{Authors' contributions}

TO and SJW conceived the experimental design. TO, SE, WNL, AHS, and SJW participated in acquisition, analysis, and interpretation of the data. TO and SJW drafted the manuscript. TO, SE, WNL, AHS, and SJW participated in critical revision and approved the final manuscript.

\section{Acknowledgements}

We thank Dr. Craig Smith for providing HeLa and HEK293 cells, Dr. Peter Kannu for providing C28 cells and Dr. Laura Zamurs for providing 597 cells. This work was supported by the National Health and Medical Research Council [49|293; 546478 S.W., 3343 I4 A.S.].

\section{References}

I. Gross DS, Garrard WT: Nuclease hypersensitive sites in chromatin. Annual review of biochemistry 1988, 57:159-197.

2. Wu C, Wong YC, Elgin SC: The chromatin structure of specific genes: II. Disruption of chromatin structure during gene activity. Cell 1979, I6(4):807-8I4.

3. Burgess-Beusse B, Farrell C, Gaszner M, Litt M, Mutskov V, RecillasTarga F, Simpson M, West A, Felsenfeld $G$ : The insulation of genes from external enhancers and silencing chromatin. Proceedings of the National Academy of Sciences of the United States of America 2002, 99(Suppl 4): 16433-16437.

4. Follows GA, Janes ME, Vallier L, Green AR, Gottgens B: Real-time PCR mapping of DNasel-hypersensitive sites using a novel ligation-mediated amplification technique. Nucleic acids research 2007, 35(8):e56.

5. Dorschner MO, Hawrylycz M, Humbert R, Wallace JC, Shafer A, Kawamoto J, Mack J, Hall R, Goldy J, Sabo PJ, et al.: High-throughput localization of functional elements by quantitative chromatin profiling. Nature methods 2004, I(3):219-225.

6. Crawford GE, Davis S, Scacheri PC, Renaud G, Halawi MJ, Erdos MR, Green R, Meltzer PS, Wolfsberg TG, Collins FS: DNase-chip: a high-resolution method to identify DNase I hypersensitive sites using tiled microarrays. Nature methods 2006, 3(7):503-509.

7. Sabo PJ, Kuehn MS, Thurman R, Johnson BE, Johnson EM, Cao H, Yu M, Rosenzweig E, Goldy J, Haydock A, et al.: Genome-scale mapping of DNase I sensitivity in vivo using tiling DNA microarrays. Nature methods 2006, 3(7):5II-518.

8. Follows GA, Dhami P, Gottgens B, Bruce AW, Campbell PJ, Dillon SC, Smith AM, Koch C, Donaldson IJ, Scott MA, et al.: Identifying gene regulatory elements by genomic microarray mapping of DNasel hypersensitive sites. Genome research 2006, 16(10):1310-1319.

9. Boyle AP, Davis S, Shulha HP, Meltzer P, Margulies EH, Weng Z, Furey TS, Crawford GE: High-resolution mapping and characterization of open chromatin across the genome. Cell 2008, 132(2):3। I-322.

10. Crawford GE, Holt IE, Whittle J, Webb BD, Tai D, Davis S, Margulies EH, Chen Y, Bernat JA, Ginsburg D, et al.: Genome-wide mapping of DNase hypersensitive sites using massively parallel signature sequencing (MPSS). Genome research 2006, 16(1):|23-131.

II. Schouten JP, McElgunn C), Waaijer R, Zwijnenburg D, Diepvens F, Pals G: Relative quantification of $\mathbf{4 0}$ nucleic acid sequences by multiplex ligation-dependent probe amplification. Nucleic acids research 2002, 30(12):e57.

12. Lalic T, Vossen RH, Coffa J, Schouten JP, Guc-Scekic M, Radivojevic D, Djurisic M, Breuning MH, White SJ, den Dunnen JT: Deletion and duplication screening in the DMD gene using MLPA. Eur J Hum Genet 2005, I3(I I): I 23 I-1234.

13. Kozlowski P, Roberts P, Dabora S, Franz D, Bissler J, Northrup H, Au KS, Lazarus R, Domanska-Pakiela D, Kotulska K, et al.: Identification of 54 large deletions/duplications in TSCI and TSC2 using MLPA, and genotype-phenotype correlations. Human genetics 2007, I 2 I(3-4):389-400.

14. Nygren AO, Ameziane N, Duarte HM, Vijzelaar RN, Waisfisz Q, Hess C], Schouten JP, Errami A: Methylation-specific MLPA (MSMLPA): simultaneous detection of CPG methylation and copy number changes of up to $\mathbf{4 0}$ sequences. Nucleic acids research 2005, 33(I4): el 28.

15. Eldering E, Spek CA, Aberson HL, Grummels A, Derks IA, de Vos AF, McElgunn CJ, Schouten JP: Expression profiling via novel multiplex assay allows rapid assessment of gene regulation in defined signalling pathways. Nucleic acids research 2003, 3I(23): el53.

16. Young JM, Endicott RM, Parghi SS, Walker M, Kidd JM, Trask BJ: Extensive copy-number variation of the human olfactory receptor gene family. American journal of human genetics 2008, 83(2):228-242.

17. White SJ, Vissers LE, Geurts van Kessel A, de Menezes RX, Kalay E, Lehesjoki AE, Giordano PC, Vosse E van de, Breuning MH, Brunner HG, et al.: Variation of CNV distribution in five different ethnic populations. Cytogenetic and genome research 2007, II8(I): 19-30.

18. Notini AJ, Li R, Western PS, Sinclair AH, White SJ: Rapid and reliable determination of transgene zygosity in mice by multiplex ligation-dependent probe amplification. Transgenic Res 2009 in press.

19. Hewitt CA, Carmichael CL, Wilkins EJ, Cannon PZ, Pritchard MA, Scott HS: Multiplex ligation-dependent probe amplification (MLPA) genotyping assay for mouse models of down syndrome. Front Biosci 2007, 12:3010-3016.

20. Leonhard WN, Roelfsema JH, Lantinga-van Leeuwen IS, Breuning MH, Peters DJ: Quantification of Cre-mediated recombination by a novel strategy reveals a stable extra-chromosomal deletion-circle in mice. BMC biotechnology 2008, 8:18.

21. Birney E, Stamatoyannopoulos JA, Dutta A, Guigo R, Gingeras TR, Margulies EH, Weng Z, Snyder M, Dermitzakis ET, Thurman RE, et al:: Identification and analysis of functional elements in $1 \%$ of the human genome by the ENCODE pilot project. Nature 2007, 447(7| 146): 799-816.

22. Harteveld CL, Voskamp A, Phylipsen M, Akkermans N, den Dunnen JT, White SJ, Giordano PC: Nine unknown rearrangements in I6pI3.3 and IIpI5.4 causing alpha- and beta-thalassaemia characterised by high resolution multiplex ligation-dependent probe amplification. Journal of medical genetics 2005, 42(1 2):922-931.

23. White SJ, Vink GR, Kriek M, Wuyts W, Schouten J, Bakker B, Breuning $\mathrm{MH}$, den Dunnen JT: Two-color multiplex ligation-dependent probe amplification: detecting genomic rearrangements in hereditary multiple exostoses. Human mutation 2004, 24(I):86-92.

24. White SJ, Breuning MH, den Dunnen JT: Detecting copy number changes in genomic DNA: MAPH and MLPA. Methods in cell biology 2004, 75:751-768. 